Journal of Finance and Banking Review

Journal homepage: www. gatrenterprise. com/GATRJournals/index. htm

J. Fin. Bank. Review 4 (2) 47-57 (2019)

\title{
An Awareness Model for an Islamic Pre-Need Funeral Plan
}

\author{
Maheran Katan ${ }^{* 1}$, Nasreen Miza Hilmy Nasrijal' ${ }^{2}$, Abd Halim Mohd Noor ${ }^{3}$, Norajila Che \\ $\operatorname{Man}^{4}$ \\ ${ }^{* 1}$ Center of Islamic Philanthropy \& Islamic Finance, Universiti Teknologi MARA, Melaka, Malaysia \\ ${ }^{2}$ Universiti Teknologi MARA, Melaka, Malaysia \\ ${ }^{34}$ Center of Islamic Philanthropy \& Islamic Finance, Universiti Teknologi MARA, Melaka, Malaysia
}

\begin{abstract}
Objective -Failure to prearrange one's funeral may lead to financial hardship on one's family members. Despite the importance of a funeral plan, little is known regarding the awareness level among Muslims regarding the Islamic Preneed Funeral Plan (IPFP). Because of the dearth of academic research on the awareness among Muslims regarding IPFP, this paper aims to assess the awareness level of Muslims regarding IPFP and to develop an awareness model that frames factors affecting IPFP awareness level.

Methodology/Technique - To achieve this, a questionnaire was used to collect the data and PLS-SEM was used to analyse the data. Results show that the level of awareness regarding IPFP is low and is similar to the result found in the USA

Findings - The results further show that marketing communication efforts and social influence are significant factors affecting awareness of IPFP. These results have practical implications for IPFP providers and should help them better market their products and mitigate the potential for financial hardship funeral costs may have on families.

Novelty - The scarcity of land for burial plots, soaring funeral costs and an increasingly aging population rate necessitates funeral prearrangements by subscribing to a pre-need funeral plan. This prearrangement is an advanced financial provision that covers funeral and burial expenses by enabling subscribers to make funeral arrangements while they are still alive.

Type of Paper: Empirical.

Reference to this paper should be made as follows: Katan, M.; Nasrijal, N. M. H.; Noor, A. H. M.; Man, N. C. (2019). An Awareness Model for an Islamic Pre-Need Funeral Plan, J. Fin. Bank. Review, 4 (2): 47 - 57 https://doi.org/10.35609/jfbr.2019.4.2(1)
\end{abstract}

Keywords: Awareness; Islamic Pre-need Funeral Plan; Marketing Communication Efforts; PLS-SEM, Social Influence. JEL Classification: I22, I30, I39.

\section{Introduction}

Deaths and funerals are inevitable events in life. As reported by Department of Statistics Malaysia, the death rate in Malaysia increased 3.6\% from 150,318 (2014) to 155,786 (2015).

\footnotetext{
* Paper Info: Received: November 12, 2018

Accepted: June 30, 2019

* Corresponding author: Maheran Katan

E-mail: maherankatan@yahoo.com

Affiliation: Universiti Teknologi Mara, Malaysia
} 
The price for funeral services and burial plots for non-Muslims in private memorial parks escalated to an average of RM50,000 (Boo, 2014). More broadly, funeral cost has increased globally due to: 1) rising cost of a burial plot along with the cost of land; and 2) soaring rate of cremation with the increase in energy prices and legal requirements for crematories to install new equipment and filters. Even though most Muslims are buried in public cemeteries, the funeral cost for Muslims has also increased over the years. Hence, there is a need to make funeral prearrangements by subscribing to a pre-need funeral plan. This advanced financial provision plan covers funeral and burial expenses, enabling subscribers to make all funeral arrangements during their lifetime. Failure to prearrange funeral costs can expose surviving family members to potential debt and further anxiety at a time when grieving family members of the deceased are vulnerable.

Customarily, the Muslim community and mosque committees handle most of the work associated with Muslim funerals. However, reliance on one's community may not be practical in urbanized Malaysia due to: 1) modernization and escalating urbanization having affected the living condition of the society and in turn, diminishing the close relationship of the community (Billig, 2016); and 2) lack of interest and knowledge of Islamic funeral management among Malaysian Muslim youth (Malay Mail Online, 2015). Financing a Muslim funeral is traditionally done through the Community Death Fund Association (Khairat Kematian) whereby money is collected from each household in an area (kariah). A participating household pays a predetermined annual instalment, fixed without actuarial calculation and possibly resulting in a shortage of funds if the actual number of deaths is more than expected. In situations where there are more deaths than expected, the government would have to absorb the funeral costs. In view of the difficulties faced by the community from more deaths than previously managed (partially due to demographic shifts), private initiatives have developed in the form of IPFP. An IPFP is run by firms that systematically collect payments and applies a takaful plan whose benefits cover the cost not only for complete Islamic funeral processes but also the following: a cash contribution to the deceased's family, a complete al-Quran reciting, a tahlil ceremony, cash waqf for the mosque in the deceased's name, a takaful Personal Accident, and estate management services.

Records from Companies Commission of Malaysia (CCM) revealed that there are companies offering IPFP. Basically, the process of IPFP involves three stages. The initial stage comprises of an interested buyer subscribing to IPFP by paying a monthly or annual fee, as prescribed by the plan. In the event of death, next of kin of the deceased subscriber only need to notify the plan provider. Subsequently, the IPFP provider will then render the necessary services in relation to the funeral processes i.e. disseminating news regarding death of a person to selected relatives using a short messaging system (SMS), securing a death registration and burial permit, washing and shrouding the body, digging the grave, preparing the hearse, conducting the burial ritual according to Shariah principles, performing prayers, reciting the Quran and erecting the grave marker. The process of a Islamic Pre-need Funeral Plan (IPFP) is depicted in Figure 1.

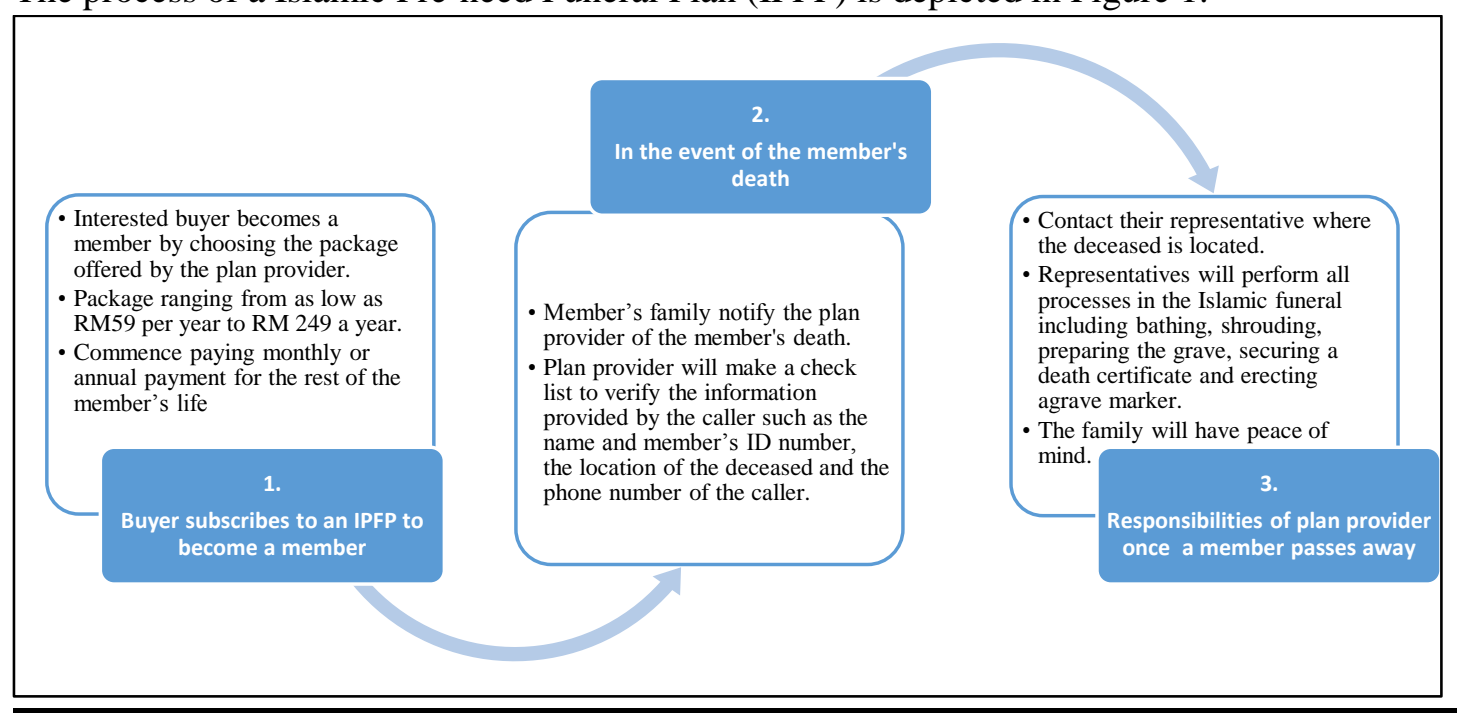


Figure 1: The Process of IPFP

To date, very limited academic research has been done on Islamic pre-need funeral plans. Most research available in the literature on funeral plans were done on non-Muslim communities in various countries such as Walsh (2011) for Thailand, Hickey and Quinn (2012) for the United Kingdom, Kemp and Koop (2010), Kopp and Kemp (2007) for the USA, Villamin (2016) for the Philippines, and Van der Laan and Moerman (2017) for Australia. Due to the paucity of studies on IPFP, this paper attempts to fill the gap in the literature and thereby assess the awareness level of Muslims regarding IPFPs and to develop an awareness model consisting of factors affecting IPFP awareness level. Study results found that the level of awareness of IPFP is low, akin to the result found in the USA. The results further show that marketing communication efforts and social influence are significant factors affecting the awareness of IPFP. These results have practical implications for IPFP providers to better market their products.

\section{Review of Literature}

The theoretical foundation for this study is the Transtheoretical Model (TMM) developed by Prochaska, Norcross and DiClemente (1994). TMM explains five stages that individuals go through for behaviour change: precontemplation, contemplation, preparation, action and maintenance. IPFP is a new product in the funeral services market. At the precontemplation stage, Muslim consumers are oblivious to IPFP. In fact, they may not comprehend the need to pre-arrange their funeral. It may take an emotional trigger, or a devastating event that raises their consciousness or awareness about the need for pre-arranging their funeral. The change at this stage could be measured through increased awareness. Guion and Free (2010) highlighted a few factors that could increase awareness. After Muslims are triggered on the need to subscribe IPFP, they might seek more information on it. The first factor is marketing communication efforts; this is where the IPFP providers must do all marketing efforts through various modes of transmitting information using powerful messages that aim to evoke an emotional need to subscribe to an IPFP. Their information seeking processes will lead to more knowledge on IPFPs. Once they perceive there are greater benefits in subscribing to an IPFP that heighten their awareness, they will move to the second stage: contemplation. In this stage they are fully aware of the pros and cons of subscribing to an IPFP and they contemplate subscribing to IPFP. The next stage is preparation, where the interested customers have a plan of action that they will embark on in the near future. The fourth stage is action itself, where the customers fill out the form to subscribe to IPFP and commence periodic payments. The last stage is maintenance, whereby the subscribers continue paying the subscription fees for the rest of their lives. In the event of their death, IPFP will be effective and their family is protected from financial and emotional burdens of managing the funeral.

\section{Awareness}

Consumers are aware of a product or service when they can recall the product even in its absence (Timiras, 2017). The level of awareness among consumers regarding pre-planning funeral arrangements in the USA is low (Kemp and Kopp, 2010; Lambert, 2016). Awareness on Islamic products other than IPFP was reported in the literature, such as awareness of takaful (Coolen-Maturi, 2013) and Islamic banking (Ul Islam and Rahman, 2017). However, awareness of IPFP has been neglected in the literature even though awareness is a prerequisite for the success of a product/service.

\section{Knowledge}

Raghuvanshi (2016) found a relationship between knowledge and awareness while Md Husin and Ab Rahman (2013) reported that better education led to higher awareness of takaful schemes. Nga et al. (2010) found an association between knowledge and financial awareness among youth. Zhang (2001) further 
demonstrated that having the cultural knowledge of relevant reading material resulted in higher awareness and understanding of the subject matter. As such, a well-informed customer on IPFP is expected to be aware of IPFP. With this in mind, Hypothesis 1 is formulated:

H1: Knowledge has a significant relationship with awareness of IPFP

\section{Perception}

Perception is the process whereby consumers receive, select, organize, and interpret sensory stimuli resulting in a valued evaluation that influence customers' awareness of a service and subsequently influence their decision making (Lantos, 2015). Awareness results from perception formed by exposure to information on the product (Hoyer and Brown, 1990). If consumers perceive IPFP has attributes and benefits that satisfy their needs and wants, their awareness of IPFP will increase. As such, H2 hypothesized that:

H2: Perception has a significant relationship with awareness of IPFP.

\section{Marketing communication efforts}

Promotional activities and multi-channel advertising are required to create awareness among potential customers (Goersch, 2002). Using multiple advertising mediums such as social media, printed media, television and face-to face events enable service providers to reach the widest audience. Alalwan et al. (2017) concluded that $89 \%$ of articles they reviewed supported the role of social media in enhancing a customer's awareness. Moreover, Keller (2001) argued that advertising and other sources of information are important to create brand awareness. Mellor (2006) concluded that promotional activities increased the awareness of English citizens to use e-channels. Hence, H3 postulated that:

H3: Marketing communication efforts have a significant relationship with awareness of IPFP.

\section{Religiosity}

Mokhlis (2006) emphasized the importance and potential of religion as an explanatory construct in predicting consumer behaviour. The religiosity of Muslims may play an important role in their awareness regarding IPFP because Muslims should constantly prepare for death. Subscribing to an IPFP is one of the steps towards preparing for death. Uyar et al. (2015) observed the relationship between religiosity and ethical awareness. Therefore, it is expected that:

H4: Religiosity has a significant relationship with awareness of IPFP

\section{Social influence}

Social influence was identified as an indicator of opinion change (Christensen and Schiaffino, 2014). Family members, neighbours, friends, colleagues, superiors and experienced individuals known by a person may influence that person to be more aware of a product or service. Members of a cohesive group are likely to be more aware of each other's opinions due to efficiency in communicating opinions among themselves (Friedkin, 2006). In investigating the respondents' awareness of energy conservation, for example, Nolan et al. (2008) found that neighbours have the strongest effect. Thus, it is hypothesized that:

H5: Social influence has a significant relationship with awareness of IPFP

\section{Research Methodology}

The objectives of this study are to investigate the level of awareness on IPFP among Muslims and to construct an awareness model for IPFP. To facilitate this, primary data were collected by using structured 
questionnaires from a sample of Muslims in Kuala Lumpur, Malaysia. We utilized a convenience sampling method because there are no inclusion criteria prior to the selection of the respondents. This sampling method is appropriate for this study to obtain primary data regarding the issue concerned. The quantitative nature of the study, which utilizes PLS-SEM in the analysis, necessitates the usage of a questionnaire survey rather than conducting qualitative interviews. A pilot study was conducted to verify the suitability of the questionnaire items. In the survey, a mall intercept approach was used to distribute the questionnaire.

The questionnaire has two sections. Section A consists of questions related to demographics of respondents and Section B measures the insights of respondents on each construct. The measurements for each latent construct were adapted from previous studies to ensure content validity. The measurement for the endogenous construct, i.e. awareness of IPFP, was adapted from Collins (2007). The exogenous constructs are: knowledge, perception, marketing communication efforts, social influence and religiosity in relation to IPFP. Measurements for exogeneous constructs are adapted from Ringim (2014), Morgan and Miller (2002), Kemp and Kopp (2010), Crosby and Stephens (1987) and Mokhlis (2006). A five-point Likert-type scale was applied to all instruments' items. The scale ranged from 1 representing strongly disagree and 5 representing strongly agree.

The partial least square structural equation model (PLS-SEM) approach was adopted in the data analysis due to the exploratory nature of this research. PLS-SEM is a regression-based approach that minimizes the residual variances of the endogenous constructs. SmartPLS 3.0 software was used to execute the analysis. As suggested by Hair et al. (2017) PLS-SEM is appropriate if data to some extent is non-normal. Assessment of multivariate skewness and kurtosis revealed that the data are not multivariate normal based on Mardia's multivariate skewness $(\beta=3.494, \mathrm{p}<0.01)$ and Mardia's multivariate kurtosis $(\beta=52.025, \mathrm{p}<0.01)$. Thus, it is appropriate to use non-parametric analysis software such as SmartPLS 3.0. There is a two-step process in PLS-SEM assessment: the measurement model and the structural model. The measurement model tests the measures' reliability and validity to ensure only reliable and valid construct measures are used in the analysis. The structural model describes the relationship between the latent variables.

A total of 400 questionnaires were distributed and 389 usable, complete responses were obtained. The minimum sample size for a PLS-SEM should be the larger of two criteria: 10 times the number of items for the most complex construct or 10 times the largest number of independent variables affecting a dependent variable. In this study, all constructs originally have five items and the largest number of independent variables estimated for a dependent variable is five. The sample size of this study exceeded the minimum sample requirement recommended by Hair et al. (2017).

\section{Results and Discussion}

\section{Respondents' Profile}

The respondents were $52 \%$ female and $48 \%$ male. More than half of the respondents $(56 \%)$ were between 25 to 40 years old. The majority of the respondents $(61 \%)$ were married. In terms of education level, $8 \%$ of respondents reported having completed only secondary school and $92 \%$ obtained tertiary qualification. Half of the respondents were in the lower middle-income category earning up to RM3,999 per month. The first objective of this study was to investigate the level of awareness regarding IPFP. Only $22 \%$ of the respondent were aware of IPFPs. Cross-tabulation analysis revealed that the majority of those who are aware of IPFPs are those respondents who are married (65\%), diploma or degree holders (76\%), and earning from RM1,000 to RM7,999 per month (84\%). It can be concluded that the level of awareness on IPFP among respondents is low and this finding is consistent with the low awareness on pre-need funeral plans in the USA.

Table 1: Respondents' Profile 


\begin{tabular}{|c|c|c|c|}
\hline & Frequency (\%) & Frequency (\%) \\
\hline Gender & & Marital Status & \\
\hline Male & $187(48 \%)$ & Married & $238(61 \%)$ \\
\hline Female & $202(52 \%)$ & Not Married & $151(30 \%)$ \\
\hline Age & & & \\
\hline$<25$ & & Education & \\
\hline $25-40$ & $30(8 \%)$ & Secondary School & $30(8 \%)$ \\
\hline $41-55$ & $217(56 \%)$ & Certificate /Diploma & $127(32 \%)$ \\
\hline$>55$ & $118(30 \%)$ & Degree/Professional & $182(47 \%)$ \\
\hline & $24(6 \%)$ & Masters and above & $50(13 \%)$ \\
\hline Employment & & & $3(1 \%)$ \\
\hline Top Management & $32(8 \%)$ & Less than RM1000 & $195(50 \%)$ \\
\hline Middle Management & $140(36 \%)$ & RM1000 - RM3,999 & $136(35 \%)$ \\
\hline First-Level Supervisor & $132(34 \%)$ & RM4000 - RM7,999 & $55(14 \%)$ \\
\hline Nonmanagerial & $85(22 \%)$ & More than RM8000 & \\
\hline Aware of IPFP & & & \\
\hline Yes & $86(22 \%)$ & & \\
\hline No & $303(78 \%)$ & & \\
\hline
\end{tabular}

\section{Measurement Model}

All items used in the study constitute a reflective measurement model because the items for each construct share a common theme and are interchangeable (Coltman et al., 2008). There are three assessments for a reflective measurement model: convergent validity (indicator reliability \& average variance extracted), internal consistency (Cronbach's alpha \& composite reliability), and discriminant validity (Fornell-Larcker criterion \& heterotrait-monotrait ratio-HTMT). Referring to Table 2, out of 30 loadings, 24 are more than 0.7 and considered as reliable. One loading of 0.6 is retained because removing it does not lead to an increase in the average variance extracted (Hair et al., 2017). Five items having loading of less than 0.4 were deleted. A sufficient level of indicator reliability is achieved when each item has outer loadings above 0.70 (Hair et al., 2014). The average variances (AVE) range from 0.569 to 0.836 , which well exceeded the recommended cut-off value of 0.5 (Fornell and Larcker, 1981), indicating a sufficient degree of convergent validity. This means the construct explains more than half of its indicators variances. Internal consistency is assessed using Cronbach's alpha and composite reliability. Cronbach's alpha for all constructs are above 0.7 and composite reliability for all constructs are well above the recommended cut-off value of 0.7 indicating a high level of internal consistency (Hair et al., 2017).

Table 2: Measurement Model Evaluation

\begin{tabular}{|c|c|c|c|c|c|}
\hline Construct & Items & Outer Loading & $\begin{array}{c}\text { Cronbach } \\
\text { Alpha }\end{array}$ & $\begin{array}{c}\text { Composite } \\
\text { Reliability }\end{array}$ & AVE \\
\hline \multirow{4}{*}{ Awareness } & AWR1 & 0.916 & 0.951 & 0.962 & 0.836 \\
\cline { 2 - 6 } & AWR2 & 0.926 & & & \\
\cline { 2 - 6 } & AWR3 & 0.925 & & & \\
\cline { 2 - 6 } & AWR4 & 0.905 & & & \\
\cline { 2 - 6 } & AWR5 & 0.900 & & & \\
\hline \multirow{7}{*}{ Knowledge } & KNW1 & 0.864 & 0.705 & & \\
\cline { 2 - 7 } & KNW2 & 0.809 & & & \\
\cline { 2 - 7 } & KNW5 & 0.600 & & & \\
\hline
\end{tabular}




\begin{tabular}{|c|c|c|c|c|c|}
\hline \multirow{4}{*}{ Perception } & PER1 & 0.846 & 0.855 & 0.793 & 0.696 \\
\hline & PER2 & 0.881 & & & \\
\cline { 2 - 6 } & PER3 & 0.860 & & & \\
\cline { 2 - 6 } $\begin{array}{c}\text { Marketing } \\
\text { communication } \\
\text { efforts }\end{array}$ & PER5 & 0.744 & & & \\
\hline Religiosity & MKT1 & 0.910 & 0.880 & 0.913 & 0.779 \\
\cline { 2 - 6 } & MKT2 & 0.908 & & & \\
\cline { 2 - 6 } & REL1 & 0.826 & & & \\
\cline { 2 - 6 } & REL2 & 0.809 & 0.900 & 0.917 & 0.690 \\
\cline { 2 - 6 } & REL3 & 0.911 & & & \\
\cline { 2 - 6 } & REL4 & 0.818 & & & \\
\cline { 2 - 6 } Influence & REL5 & 0.790 & & & \\
\hline \multirow{4}{*}{$\begin{array}{c}\text { Social } \\
\end{array}$} & SOC1 & 0.861 & 0.886 & 0.917 & \\
\cline { 2 - 6 } & SOC2 & 0.816 & & & \\
\cline { 2 - 6 } & SOC3 & 0.776 & & & \\
\cline { 2 - 6 } & SOC4 & 0.804 & & & \\
\cline { 2 - 6 } & SOC5 & 0.884 & & & \\
\hline
\end{tabular}

Discriminant validity implies that a construct is empirically distinct from other constructs, hence, the construct measures what it is supposed to measure. Discriminant validity is established in this study because all diagonal values of AVEs are larger than the off-diagonal values of square correlation between latent constructs. Another evaluation for discriminant validity is the heterotrait-monotrait ratio (HTMT), which is an estimate of what the true correlation between two constructs would be if they were perfectly measured. The HTMT values for all cases are below the threshold of 0.85 or 0.90 (Henseler et al., 2015). These results confirm that discriminant validity exists in this study.

\section{Structural Model}

Once satisfactory results are achieved in the measurement model and the constructs are validated, the next step is to evaluate the structural model. Structural model assessment is done to examine the relationship between constructs and includes the estimates of the path coefficients $(\beta)$ and the model predictive capabilities. Table 3 summarizes the results for the structural model. Following the steps and procedures proposed by Hair et al. (2017), the first step to evaluate the structural model of reflective constructs is to assess collinearity to ensure there is no bias in the path coefficient using the variance inflation factor (VIF). All VIF values are well below the threshold of 5.0, indicating no potential collinearity problem. The second step is to examine the structural model path coefficient, which represent the hypothesized relationships linking the constructs and their level of significance. H1 proposes a significant relationship between KNW and AWR, which is not supported $(\beta=0.060, p>0.1)$. H2 implies there is a significant relationship between perception and awareness of IPFP, and also is not supported $(\beta=-0.057, p>0.10)$. H3 proposes marketing communication efforts influence awareness of IPFP and is supported $(\beta=0.606, p<0.01)$. The results did not support H4, which proposes a significant relationship between religiosity and awareness of IPFP $(\beta=0.055, p$ $>0.1$ ). Finally, $\mathrm{H} 5$ which hypothesizes a significant relationship between social influence and awareness of IPFP is supported $(\beta=0.164, \mathrm{p}<0.01)$. The third step is to evaluate the model's predictive power using the coefficient of determination (R2), which is the portion of variance in endogenous construct explained by exogenous constructs. The results suggest that the model can explain $45.4 \%$ of the variance in AWR. In 
terms of effect size (f2), MKT has a large effect on AWR with an $\mathrm{f} 2$ of 0.52 , whereas SOC has a small effect with an $\mathrm{f} 2$ of 0.032 . An additional assessment for model fitness is Q2 (cross-validated redundancy). The Q2 for this study is 0.354 , which is greater than the benchmark Q2 value greater than 0 , indicating that the model has predictive relevance. In short, the model has acceptable fit and predictive relevance.

Table 3: Assessment of Structural Model

\begin{tabular}{|c|c|c|c|c|c|c|}
\hline Hypothesis & Relationship & $\mathbf{R 2}$ & $\boldsymbol{\beta}$ & T Statistica & VIF & Decision \\
\hline H1 & KNW->AWRb & & 0.060 & 1.179 & 1.686 & Not supported \\
\hline H2 & PER->AWR & & -0.057 & 0.899 & 2.154 & Not supported \\
\hline H3 & MKT->AWR & & 0.606 & $15.362 * * *$ & 1.294 & Supported \\
\hline H4 & REL->AWR & & 0.055 & 0.872 & 1.072 & Not supported \\
\hline H5 & SOC->AWR & 0.454 & 0.164 & $2.968 * * *$ & 1.564 & Supported \\
\hline
\end{tabular}

a t values for two-tailed test: 1.65 (sig. level 0.10), **1.96 (sig. level 0.05), and ***2.57 (sig. level =0.01), b AWR = Awareness; KWN = Knowledge; PER = Perception; MKT = Marketing communication efforts; REL = Religiosity; SOC $=$ Social influence.

This study sets out to investigate the awareness level of Muslims on IPFP and to construct an awareness model for IPFPs. In view of Malaysia's aging society, the scarcity of land for burial plots and the rising cost of funerals, prearranging a funeral by paying a minimal monthly amount is sensible. However, the evidence from this study suggests that the awareness level among Muslims on IPFP is low. Death has financial implications not only to the deceased's family but also to society. Funeral costs may become a policy issue such as the funeral welfare available in the UK. Malaysia may have to implement a funeral welfare system if Malaysians do not practice financial preplanning for funerals. Policy makers need to collaborate with service providers in promoting the awareness of IPFPs through campaigns and other mediums. Offering incentives through personal tax relief may also encourage people to subscribe to an IPFP.

In the proposed awareness model, marketing communication efforts and social influence have a significant relationship with the awareness of IPFPs. These two constructs are also found to be significant in the funeral planning process (Kemp and Kopp, 2010). There is a dearth of studies on awareness of IPFPs. However, recent studies have reported the effect of marketing communication efforts on awareness on a variety of services, such as for fund-raising activities (Veríssimo et al., 2017), the use of academic e-books by library users (Raynard, 2017), and volunteer recruitment and retention (Crall et al., 2017). Likewise, the impact of social influence on awareness was also reported in the literature, such as Hutter et al. (2013) who investigated the impact of social media on brand awareness, and Gaspar et al. (2016) who examined the effect of social influence on eating awareness among children.

Because marketing communication efforts have a large effect on awareness of IPFPs, service providers should seriously consider extensive promotional strategies for their services. To glean further insight into marketing communication efforts, respondents rated "face-to-face" marketing communication as the most effective promotion for IPFPs. In dealing with issues as delicate and as sensitive as death and funerals, marketers of IPFPs should opt for face-to-face meetings with potential clients because it builds a relationship and ultimately, trust. Excellent marketing relationships with personalized service would lead to additional referrals through word of mouth promotion. The significant relationship of social influence on awareness of IPFPs may provide interesting insight for IPFP marketers. Family members should be encouraged to subscribe to IPFPs as a unit with appropriate discounts or incentives provided. Subscribing to an IPFP together as a family will avoid the occurrence of funeral poverty since all family members will be protected by the IPFP. 


\section{Conclusions}

It was reported that one in three Malaysians does not have a savings account; $90 \%$ of rural households have zero savings, and $86 \%$ of urban households do not have savings (Shagar, 2016). Given the low amount of savings, most families may not be able to afford proper funerals for their loved ones. Failure to prearrange a funeral may lead to funeral poverty and financial hardship due to a lack of resources for the funeral. Funeral poverty, an emerging concept to describe the distress experienced by people with limited resources to pay for huge funeral costs (Corden and Hirst, 2015), is predicted as the next social crisis for families in the UK and USA; Malaysia is likely to join them. The impending funeral poverty crisis presents a challenge to governments to ensure a sustainable social welfare and benefit system while being fair to the taxpayers. Preneed funeral plans can be a solution to the funeral poverty crisis because subscribers set aside an amount of funds for their funeral, eliminating the need for government assistance. The present study provides evidence that awareness of IPFPs is low, thus concerted efforts from all parties involved are needed to boost awareness of IPFPs in Malaysia. As an extension to this study, it will be interesting to compare the level of awareness between various communities and factors influencing their awareness on funeral pre-arrangements.

\section{Acknowledgements}

Sincere appreciation goes to Kementerian Pendidikan Malaysia (KPM), Fundamental Research Grant Scheme (FRGS) [600-IRMI/FRGS 5/3 (28/2016)], RMI, and UiTM for the support given in this research endeavour.

\section{References}

Alalwan, A. A., Rana, N. P., Dwivedi, Y. K., \& Algharabat, R. (2017). Social media in marketing: A review and analysis of the existing literature. Telematics and Informatics, 34(7), 1177-1190. http://dx.doi.org/10.1016/j.tele.2017.05.008

Billig, M. (2016). Effects of the forced resettlement of a community from an agricultural settlement to a high-rise building. GeoJournal, 81(1), 123-137. http://agris.fao.org/agris-search/search.do?recordID=US201600127273

Boo, S, L. (2014), "Even in death, no escape from rising prices", The MalayMail Online, 11 April, available at: http://www.themalaymailonline.com/malaysia/article/even-in-death-no-escape-from-rising-

prices\#KzGGLSLWeU8usdJ7.97 (accessed 13 November 2017)

Alina Christensen, I., \& Schiaffino, S. (2014). Social influence in group recommender systems. Online Information Review, 38(4), 524-542. https://www.emerald.com/insight/content/doi/10.1108/OIR-08-2013-0187/full/html https://doi.org/10.1108/OIR-08-2013-0187

Collins, C. J. (2007). The interactive effects of recruitment practices and product awareness on job seekers' employer knowledge and application behaviors. Journal of applied psychology, 92(1), 180. https://doi.org/10.1037/00219010.92.1.180

Coltman, T., Devinney, T. M., Midgley, D. F., \& Venaik, S. (2008). Formative versus reflective measurement models: Two applications of formative measurement. Journal of Business Research, 61(12), 1250-1262. http://dx.doi.org/10.1016/j.jbusres.2008.01.013

Coolen-Maturi, T. (2013). Islamic insurance (takaful): demand and supply in the UK. International Journal of Islamic and Middle Eastern Finance and Management, 6(2), 87-104. https://doi.org/10.1108/17538391311329806

Corden, P. A., \& Hirst, M. A. (2016). The Meaning of Funeral Poverty: an exploratory study.

Crall, A., Kosmala, M., Cheng, R., Brier, J., Cavalier, D., Henderson, S., \& Richardson, A. (2017). Volunteer recruitment and retention in online citizen science projects using marketing strategies: lessons from Season Spotter. Journal of Science Communication, 16(1), A01. https://doi.org/10.22323/2.16010201

Crosby, L. A., \& Stephens, N. (1987). Effects of relationship marketing on satisfaction, retention, and prices in the life insurance industry. Journal of marketing research, 24(4), 404-411. https://doi.org/10.1007/978-3-662-09745-8_1

Fornell, C., \& Larcker, D. F. (1981). Evaluating structural equation models with unobservable variables and measurement error. Journal of marketing research, 18(1), 39-50. DOI: 10.2307/3151312 
Friedkin, N. E. (2006). A structural theory of social influence (Vol. 13). Cambridge University Press. https://doi.org/10.1016/j.ifacol.2017.08.1139

Gaspar de Matos, M., Palmeira, A. L., Gaspar, T., De Wit, J. B., \& Luszczynska, A. (2016). Social support influences on eating awareness in children and adolescents: the mediating effect of self-regulatory strategies. Global public health, 11(4), 437-448.

Goersch, D. (2002). Multi-channel integration and its implications for retail web sites. ECIS 2002 Proceedings, 11. available at http://aisel.aisnet.org/cgi/viewcontent.cgi?article=1015\&context=ecis2002 (accessed 13 November 2017)

Guion, L.A. and Free, T.R., (2010), "A conceptual framework for infusing behavior change theories into program design, delivery and evaluation: A financial education example", The Forum for Family and Consumer Issues, e-journal Vol. 15, No. 1, available at https://projects.ncsu.edu/ffci/publications/2010/v15-n1-2010-spring/guion-free.php (accessed 13 November 2017).

F. Hair Jr, J., Sarstedt, M., Hopkins, L., \& G. Kuppelwieser, V. (2014). Partial least squares structural equation modeling (PLS-SEM) An emerging tool in business research. European Business Review, 26(2), 106-121. 10.1108/EBR-10-2013-0128

Hair, J. F., Hult, G. T. M., Ringle, C. and Sarstedt, M. (2017), A primer on partial least squares structural equation modeling (PLS-SEM), Sage Publications, Los Angeles, USA.

Henseler, J., Ringle, C. M., \& Sarstedt, M. (2015). A new criterion for assessing discriminant validity in variance-based structural equation modeling. Journal of the academy of marketing science, 43(1), 115-135. https://doi.org/10.1007/s11747-014-0403-8

Hickey, D., \& Quinn, S. (2012). 'I don't want to talk about it.'Raising public awareness of end-of-life care planning in your locality. International journal of palliative nursing, 18(5), 241-247. https://doi.org/10.12968/ijpn.2012.18.5.241

Hoyer, W. D., \& Brown, S. P. (1990). Effects of brand awareness on choice for a common, repeat-purchase product. Journal of consumer research, 17(2), 141-148. http://dx.doi.org/10.1086/208544

Hutter, K., Hautz, J., Dennhardt, S. and Füller, J. (2013), "The impact of user interactions in social media on brand awareness and purchase intention: the case of MINI on Facebook", Journal of Product \& Brand Management, Vol. 22 No. 5/6, pp.342-351. https://doi.org/10.1108/JPBM-05-2013-0299

Keller, K. L. (2001). Building customer-based brand equity: A blueprint for creating strong brands (pp. 3-27). Cambridge, MA: Marketing Science Institute.

Kemp, E., \& Kopp, S. W. (2010). Have you made plans for that big day? predicting intentions to engage in funeral planning. Journal of Marketing Theory and Practice, 18(1), 81-90. https://doi.org/10.2753/MTP1069-6679180106

Kopp, S. W., \& Kemp, E. (2007). Consumer awareness of the legal obligations of funeral providers. Journal of Consumer Affairs, 41(2), 326-340. https://doi.org/10.1111/j.1745-6606.2007.00083.x

Lambert, D. (2016), “3 Reasons Your Pre-Need Funeral Planning Program Isn't What It Could Be” available at: https://www.homesteaderslife.com. (accessed 13 November 2017).

Lantos, G. P. (2015). Consumer behavior in action: Real-life applications for marketing managers. Routledge.

Malay Mail Online. (2015), "Elak lambat kebumi, Kelantan digesa ramaikan pengurus jenazah”, 26 December 2015 , available at: http://www.themalaymailonline.com/projekmmo/berita/article/elak-lambat-kebumi-kelantan-digesaramaikan-pengurusjenazah\#sthash.LniqFWvc.dpuf

Md Husin, M., \& Ab Rahman, A. (2013). What drives consumers to participate into family takaful schemes? A literature review. Journal of Islamic Marketing, 4(3), 264-280.

Mellor, N. (2006, September). E-citizen: Developing research-based marketing communications to increase awareness and take-up of local authority e-channels. In Aslib Proceedings (Vol. 58, No. 5, pp. 436-446). Emerald Group Publishing Limited.

Mokhlis, S. (2006), "The effect of religiosity on shopping orientation: An exploratory study in Malaysia", Journal of American Academy of Business, Vol. 9 No. 1, pp. 64-74.

Morgan, S., \& Miller, J. (2002). Communicating about gifts of life: The effect of knowledge, attitudes, and altruism on behavior and behavioral intentions regarding organ donation. Journal of Applied Communication Research, 30(2), 163178.

Nga, J. K., Yong, L. H., \& Sellappan, R. D. (2010). A study of financial awareness among youths. Young Consumers, 11(4), 277-290. https://doi.org/10.1108/17473611011093916

Nolan, J. M., Schultz, P. W., Cialdini, R. B., Goldstein, N. J., \& Griskevicius, V. (2008). Normative social influence is underdetected. Personality and social psychology bulletin, 34(7), 913-923. https://doi.org/10.1177/0146167208316691 
Prochaska, J. O., Norcross, J. C., \& DiClemente, C. C. (1994). Changing for good. New York: William Morrow and Company. Inc./Avon Books.

Raghuvanshi, M. (2016). Knowledge and Awareness: Linear Regression. Educational Process: International Journal (EDUPIJ), 5(4), 279-292. DOI: 10.22521/edupij.2016.54.2

Raynard, M. (2017). Understanding academic e-books through the diffusion of innovations theory as a basis for developing effective marketing and educational strategies. The Journal of Academic Librarianship, 43(1), 82-86. 10.1016/j.acalib.2016.08.011

Jinjiri Ringim, K. (2014). Perception of Nigerian Muslim account holders in conventional banks toward Islamic banking products. International Journal of Islamic and Middle Eastern Finance and Management, 7(3), 288-305.

Shagar, K.L. (2016, 4 May), "Malaysians not saving enough for retirement", The StarOnline, available at: http://www.thestaronline.com (accessed 13 November 2017).

Timiras, L. C. (2016). Romanian Brands Awareness Among Young People. The Case of Common Food Products. Studies And Scientific Researches. Economics Edition, (24), http://dx.doi.org/10.29358/sceco.v0i24.366

Islam, J. U., \& Rahman, Z. (2017). Awareness and willingness towards Islamic banking among Muslims: An Indian perspective. International Journal of Islamic and Middle Eastern Finance and Management, 10(1), 92-101. https://doi.org/10.1108/IMEFM-01-2016-0017

Uyar, A., Kuzey, C., Güngörmüs, A. H., \& Alas, R. (2015). Influence of theory, seniority, and religiosity on the ethical awareness of accountants. Social Responsibility Journal, 11(3), 590-604. https://doi.org/10.1108/SRJ-06-2014-0073 van der Laan, S., \& Moerman, L. C. (2017). An Investigation of Death Care and the Funeral Industry in Australia. Veríssimo, D., Vaughan, G., Ridout, M., Waterman, C., MacMillan, D., \& Smith, R. J. (2017). Increased conservation marketing effort has major fundraising benefits for even the least popular species. Biological conservation, 211, 95-101. Villamin, J. M. (2016). Availment of funeral planning management service among Chinese and Filipino: Preparation of a service development package for a funeral event business. Journal of Business on Hospitality and Tourism, 2(1), 434441, https://jbhost.org/jbhost/index.php/jbhost/article/view/78

Walsh, J. (2011). Suriya Coffins: traditions become market opportunities. Society and Business Review, 6(2), 168-175, https://doi.org/10.1108/17465681111143984

Jun Zhang, L. (2001). Awareness in reading: EFL students' metacognitive knowledge of reading strategies in an acquisition-poor environment. Language awareness, 10(4), 268-288, https://doi.org/10.1080/09658410108667039 